\title{
Functional immunoglobulin transgenes guide ordered B-cell differentiation in Rag-1-deficient mice
}

\author{
Eugenia Spanopoulou, ${ }^{1}$ Christopher A.J. Roman, ${ }^{1}$ Lynn M. Corcoran, ${ }^{2}$ Mark S. Schlissel, $^{3}$ \\ Daniel P. Silver, ${ }^{4,8}$ David Nemazee, ${ }^{5}$ Michel C. Nussenzweig, ${ }^{1,6}$ Susan A. Shinton, \\ Richard R. Hardy, ${ }^{7}$ and David Baltimore ${ }^{1,9}$ \\ ${ }^{1}$ Rockefeller University, ${ }^{6}$ Howard Hughes Medical Institute, New York, New York 10021 USA; ${ }^{2}$ Walter and Eliza Hall \\ Institute, Victoria 3050, Australia; ${ }^{3}$ Johns Hopkins University, School of Medicine, Department of Molecular Biology \\ and Genetics, Baltimore, Maryland 21205 USA; ${ }^{4}$ Whitehead Institute for Biomedical Research, Cambridge, Massachusetts \\ 02142 USA; ${ }^{5}$ Department of Pediatrics, National Jewish Center for Immunology and Respiratory Medicine, Denver, \\ Colorado 80206 USA; $^{7}$ Institute for Cancer Research, Fox Chase Cancer Center, Philadelphia, Pennsylvania 19111 USA
}

We have examined the regulatory role of the individual components of the immunoglobulin antigen receptor in B-cell development by transgenic complementation of Rag-1 deficient $\left(\mathrm{Rag}^{-}{ }^{-}\right)$mice. Complementation with a membrane $\mu$ heavy chain $\left(\mu \mathrm{HC}\right.$ ) gene allows progression of developmentally arrested Rag-1 ${ }^{-}$ pro-B-cells to the small pre-B cell stage, whereas the introduction of independently integrated $\mu \mathrm{HC}$ and $\kappa$ light chain $(\kappa L C)$ transgenes promotes the appearance of peripheral lymphocytes which, however, remain unresponsive to external stimuli. Complete reconstitution of the B-cell lineage and the emergence of functionally mature Rag-1 ${ }^{-}$peripheral $B$ cells is achieved by the introduction of cointegrated heavy and light chain transgenes encoding an anti-H-2 ${ }^{k}$ antibody. This experimental system demonstrates the competence of the $\mu \mathrm{HC}$ and $\kappa L C$ to direct and regulate the sequential stages of $B$-cell differentiation, defines the time at which negative selection of self-reactive $B$ cells occurs, and shows that elimination of these cells occurs equally well in the absence of Rag-1 as in its presence. These data also support the hypothesis that Rag-1 directly participates in the $V(D) J$ recombination process.

[Key Words: Rag-1 function; Rag-1 deficiency; immunoglobulin transgenes; immunoglobulins in B-cell differentiation; negative selection]

Received January 19, 1994; revised version accepted February 25, 1994.

Cells of the mammalian immune system develop through an orderly process of differentiation, the end result of which is antigen-responsive $B$ and $T$ cells with individual immunoglobulin or T-cell receptor (TCR) surface receptors. In the murine bone marrow (BM), the sequential stages of B-cell differentiation have been classified into seven distinct fractions defined by surface antigenic characteristics (Hardy et al. 1991). The earliest large B-cell progenitors express CD43/S7 and differentially display B220/CD45R, HSA/30F1, and BP-1 surface markers and ordered rearrangements in the IgH loci (Ehlich et al. 1993; Li et al. 1993). Differentiation to the small pre-B-cell stage correlates with productive IgH rearrangements and the loss of CD43 expression.

In pre-B cells, the newly generated $\mu$ molecules reside predominantly in the cytoplasm (for review, see Rolink and Melchers 1991; Lassoued et al. 1993). A number of

${ }^{8}$ Present address: University of California, San Francisco, California 94143 USA.

${ }^{9}$ Corresponding author. studies suggest that $\mu$ can also emerge on the surface of a transient BM subpopulation complexed with the two surrogate light-chain (SLC) molecules $\lambda 5$ and $\mathrm{V}_{\text {preB }}$ (Pillai and Baltimore 1987; Kerr et al. 1989; Karasuyama et al. 1993; Takemori et al. 1990; Tsubata and Reth, 1990; Cherayil and Pillai 1991; Misener et al. 1991; Nishimoto et al. 1991; Bossy et al. 1993; Lassoued et al. 1993). Surface expression of $\mu$ requires the additional appearance of the IgM auxilliary molecules $\operatorname{Ig} \alpha$ and $\operatorname{Ig} \beta$ (Nakamura et al. 1992). It has been suggested that at this particular checkpoint of B-cell development, $\mu$ has the dual role of promoting exclusion of the allelic IgH locus (Alt et al. 1984, 1987; Nussenzweig et al. 1987; Manz et al. 1988) and activation of transcription and rearrangement in the $\kappa$ locus (Reth et al. 1987; Iglesias et al. 1991; Tsubata et al. 1992; Shapiro et al. 1993). Mutant mice lacking the ability to synthesize the membrane form of $\mu$ heavy chain $(\mu \mathrm{HC})(\mu \mathrm{mT})$ fail to produce mature B cells and fail to exert exclusion at the allelic heavy-chain locus (Kitamura et al. 1991; Kitamura and Rajewsky 1992).

Following the expression of a functional $\mu$, the fre- 
quency of $V_{\mathrm{K}}$-to- $I_{\mathrm{K}}$ rearrangements increases resulting in the production of a functional klight chain ( $\mathrm{kLC}$ ) (Alt et al. 1987; Schlissel and Baltimore 1989; Schlissel et al. 1991a; Ehlich et al. 1993). The appearance of surface immunoglobulin $\mu+\kappa$ (IgM) receptor coincides with decreased levels of the SLC. Subsequently, cells display homing receptors (Clark and Lane 1991) and acquire competence to populate peripheral lymphoid organs. In contrast, B cells carrying immunoglobulin receptors with specificity for self-antigens undergo clonal deletion (Burnet 1959; Nemazee and Burki 1989a,b). In this way the organism eliminates inappropriate antigen receptor specificities soon after their genesis.

The genesis and diversity of antigen receptors is established by somatic rearrangements of their composite gene segments (Tonegawa 1983; Schatz et al. 1992). This process, termed $V(D) I$ recombination, employs ubiquitous components that include the scid (Bosma and Carol 1991), XR-1, and xrs-6 (Taccioli et al. 1993) activities, as well as the lymphoid-specific components Rag-1, Rag-2 (Schatz et al. 1989; Oettinger et al. 1990) and terminal deoxytransferase (TdT) (Landau et al. 1987; Gilfillan et al. 1993; Komori et al. 1993). Rag-1 and Rag-2 were identified by virtue of their ability to activate $V(D) J$ recombination of an artificial recombination substrate in fibroblast cell lines (Schatz et al. 1989; Oettinger et al. 1990). Their expression precedes antigen receptor rearrangement, and they are down-modulated by receptor engagement (Turka et al. 1991; Brandle et al. 1992; Ma et al. 1992). Mice homozygously deleted for either Rag-1 or Rag-2 show an arrest in lymphoid development at the point at which $V(D) I$ recombination of TCR or immunoglobulin loci would normally occur and are immunodeficient because of the lack of any functional $B$ or $T$ cells (Mombaerts et al. 1992a; Shinkai et al. 1992; L. Corcoran, E. Spanopoulou, and D. Baltimore, this study and unpubl.).

The early arrest of lymphoid development in Rag-1 mice does not allow the study of any possible functions of Rag-1 at later stages. By examining the influence of components of the immunoglobulin receptor on B-cell lineage progression in a Rag-1 ${ }^{-}$background, their indi- vidual capabilities can be assessed and additional roles of Rag-1 beyond that of joining receptor gene segments could be uncovered. Thus, we have used transgenic complementation in the Rag-1- background to investigate the regulatory role of the individual components of the IgM receptor during the different stages of B-cell differentiation. We find that despite the absence of Rag-1, the $\mu$ plus $\kappa$ chains of an authentic antibody can fully rescue Rag-1 - B-lymphoid development, whereas $\mu$ alone can guide partial differentiation and a random $\mu$ plus $\kappa$ combination allows only partial reconstitution.

\section{Results}

\section{Rag-1 deficiency causes arrest of $B$ - and $T$-cell development}

To generate mice deficient for the Rag-1 protein (Rag$1^{-}$, we constructed an insertion vector that disrupts the coding region of the Rag-1 gene at amino acid 330 (see Materials and methods). Examination of the immune system of Rag-1 - homozygous mutant mice revealed the absence of any mature B or $\mathrm{T}$ cells in the periphery. In the thymus, $\mathrm{T}$ cells were arrested at the $\mathrm{CD} 4^{-} / \mathrm{CD} 8^{-}$ stage, prior to the point at which recombination of the TCR loci would normally occur (data not shown). The antigen receptor loci in Rag-1 ${ }^{-}$lymphoid precursors remained in germ-line configuration despite the fact that they were transcriptionally active (data not shown). These data are in accordance with previous observations on Rag-1 ${ }^{-}$(Mombaerts et al. 1992a) or Rag-2- (Shinkai et al. 1992/ mice.

To analyze the stages of arrest of BM B-cell development, surface phenotypes were determined by FACS. For this purpose, seven fractions were distinguished according to previously defined criteria as presented in Table 1 (Hardy et al. 1991; Ehlich et al. 1993; Li et al. 1993). The $\mathrm{B} 220^{+} / \mathrm{CD} 43^{+}$cells were subdivided into fractions A, B, $\mathrm{C}$, and $\mathrm{C}^{\prime}$ by their content of BP-1 and HSA (Fig. 1). In the Rag-1 $1^{-}$mice, B-cell development was arrested in fraction $\mathrm{C}$ as indicated by the high levels of cells with HSA and $\mathrm{BP}-1$ and the absence of $\mathrm{CD}_{4}{ }^{-}$cells that are the

Table 1. Stage-specific markers during B-cell differentiation in BM

\begin{tabular}{|c|c|c|c|c|c|c|c|}
\hline \multirow[b]{3}{*}{ Markers } & \multicolumn{7}{|c|}{ Stage (fractions) } \\
\hline & \multicolumn{4}{|c|}{ pro-B } & \multirow{2}{*}{$\begin{array}{l}\text { pre-B } \\
\text { (D) }\end{array}$} & \multirow{2}{*}{$\begin{array}{l}\text { immature B } \\
\text { (E) }\end{array}$} & \multirow{2}{*}{$\begin{array}{l}\text { mature B } \\
\text { (F) }\end{array}$} \\
\hline & (A) & (B) & (C) & $\left|C^{\prime}\right\rangle$ & & & \\
\hline $\mathrm{CD} 43 / \mathrm{S} 7$ & ++ & + & + & + & - & - & - \\
\hline $\mathrm{B} 220 / \mathrm{CD} 45 \mathrm{R}$ & + & + & + & ++ & ++ & ++ & +++ \\
\hline $\mathrm{HSA} / 30 \mathrm{~F} 1$ & - & + & + & +++ & ++ & + & $-1+$ \\
\hline BP-1 & - & - & ++ & ++ & + & - & - \\
\hline$\lambda 5$ & - & ++ & ++ & ++ & + & + & - \\
\hline$D_{\mathrm{H}}$ to $/_{\mathrm{H}}$ & + & ++ & ++ & + & + & - & - \\
\hline$V_{\mathrm{H}}$ to $D /_{\mathrm{H}}$ & - & - & + & ++ & $++t$ & + & - \\
\hline$V_{\mathrm{k}}$ to $I_{\mathrm{k}}$ & - & - & - & + & +++ & + & - \\
\hline
\end{tabular}

The data are based on studies by Hardy et al. (1991), Ehlich et al. (1993), and Li et al. (1993). 
Spanopoulou et al.

Figure 1. Flow cytometric analysis of $B M$ cells derived from Rag- $1^{-}$mice. Cells from BM of Rag-1 - or wild-type mice were resolved by four color FACS analysis for the surface markers B220/CD45R, CD43/S7, 30F1/HSA, and 30BP-1 (Hardy et al. 1991).
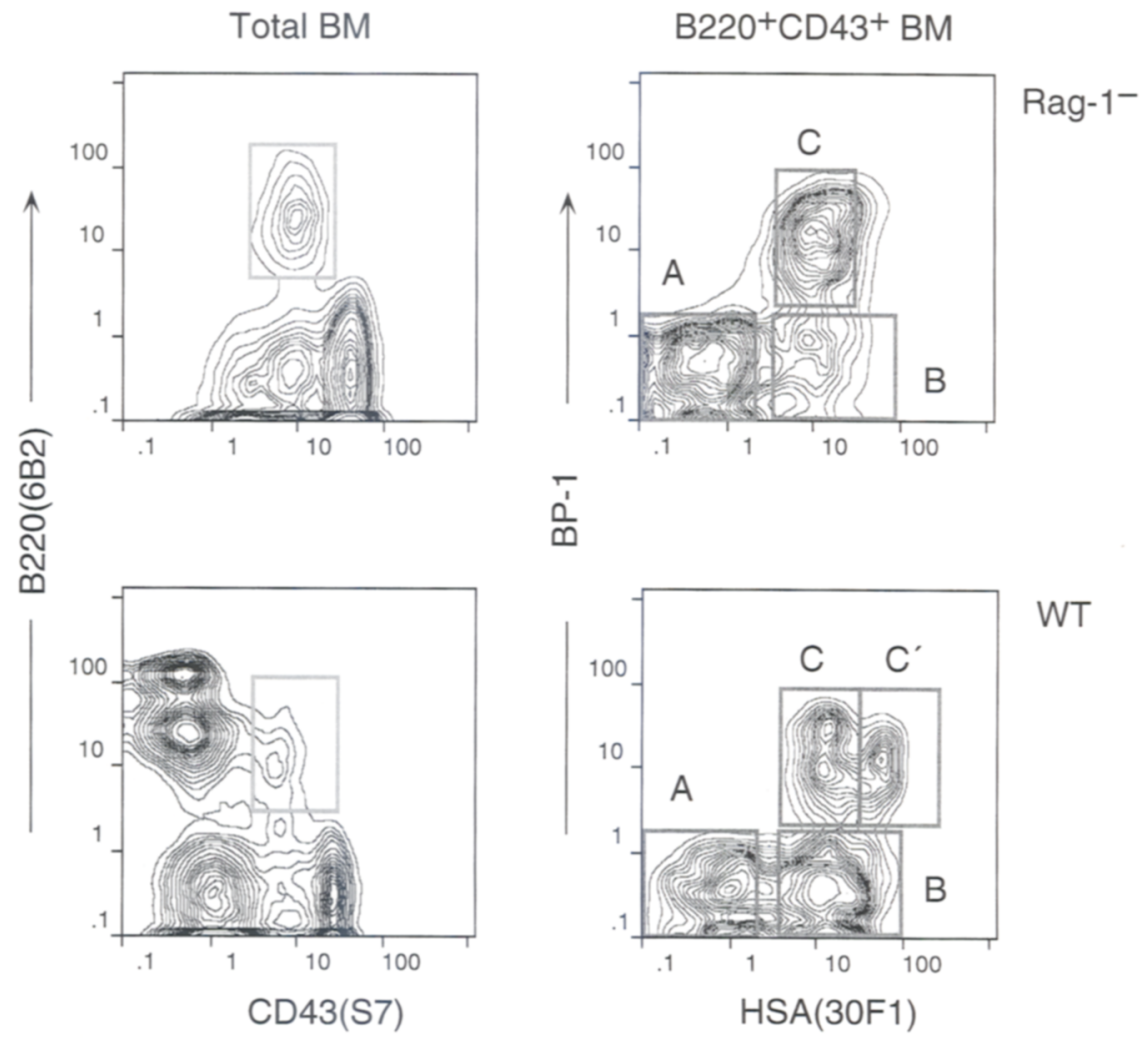

predominant ones in wild-type marrow (Fig. 1). Although fraction $C$ was over-represented, cells failed to proceed to the very high HSA state of the $\mathrm{C}^{\prime}$ fraction and fraction $\mathrm{B}$ was variable from animal to animal (Fig. 1, data not shown). Thus, B-cell development was arrested at the stage at which a functional $\mu$ would have been formed in normal mice. To examine whether the introduction of functional immunoglobulin receptors can override this developmental block, we complemented the Rag- ${ }^{-}$ germ line with rearranged $\mu$ and $\kappa$ transgenes.

Generation and FACS analysis of Rag-1-/ $\mu$ and Rag- $1^{-} / \mu \kappa$ mice

To generate a Rag-1-/ $1^{-}$genotype, the Rag-1-deficient mice were crossed to transgenic mice expressing high levels of the membrane form of a human $\mu \mathrm{HC}$ under the regulatory influence of the $\mathrm{IgH}$ intronic enhancer. In these mice, the transgenic receptor promotes complete allelic exclusion of the endogenous IgH loci (Nussenzweig et al. 1987). No murine $\mu$ could be detected on the surface of wt $/ \mu$ B cells (data not shown). A complete analysis of B-cell developmental fractions on a wild-type and Rag- $1^{-}$background is shown in Figure 2 . Whereas lymphoid development was arrested in fraction C in Rag$1^{-}$mice (Fig. 2, B1), the expression of a transgenic $\mu \mathrm{HC}$ alleviated this block and allowed B-cell development to proceed to the small pre-B cell stage (Fig. 2, B2, fraction D). The cells arrest in the stage at which recombination of the light-chain loci would normally occur (Table 1).
Surface expression of the transgenic $\mu$ protein remained undetectable by FACS analysis (Fig. 2, A2) despite its high levels in the cytoplasm (data not shown). Hence, the expression of the membrane form of $\mu$ was sufficient to shift cells from fraction C to D but little, if any, $\mu$ protein was evident on the cell surface.

To study the contribution of the $\mathrm{KLC}$ to early stages of B-cell development, Rag- $1^{-} / \mu \kappa$ double transgenic mice were generated by backcrossing the $\mathrm{Rag}-\mathrm{1}^{-/} / \mu$ line to transgenic mice expressing a murine $\mathrm{kLC}$ regulated by the $\kappa$ intronic enhancer. In the latter, the $\kappa$ transgene is expressed at high levels in B cells and promotes allelic exclusion of the endogenous $\kappa$ loci (Brinster et al. 1983; Storb 1987). In the Rag-1-/ ${ }^{-} \kappa$ double transgenic mice, expression of the transgenic $k$ allowed differentiation of the small pre-B cells to the IgM ${ }^{+}$immature B-cell stage (fraction E) (Fig. 2, A4 and B4). The transgenic human $\mu$ chain emerged on the surface complexed to the transgenic murine $\kappa$ (Fig. 2, A4) and the cells were capable of exiting the BM and populating the peripheral lymphoid organs (Fig. 2, C4). Compared with wild type (Fig. 2, A/B8), however, lymphoid development in the Rag-1-/ $\mu \kappa$ mice was still partly impaired. Specifically, there was a higher representation of pro-B cells (Fig. 2, cf. B4 with B81, the number of $\operatorname{IgM}^{+} / \mathrm{B}_{2} 20^{\text {high }}$ cells in the $\mathrm{BM}$ was significantly lower and these cells did not proceed to the B220 $0^{\text {bright }}$ stage (Fig. 2, cf. A/B4 with A/B5). In the Rag$1^{-} / \mu \mathrm{K}$ spleen, the total number of $\operatorname{IgM}^{+}$cells was reduced and an intermediate subpopulation of $\mathrm{B} 220^{+} /$ $\mathrm{IgM}^{-}$cells appeared (Fig. 2, cf. C4 with C5). The splenic 


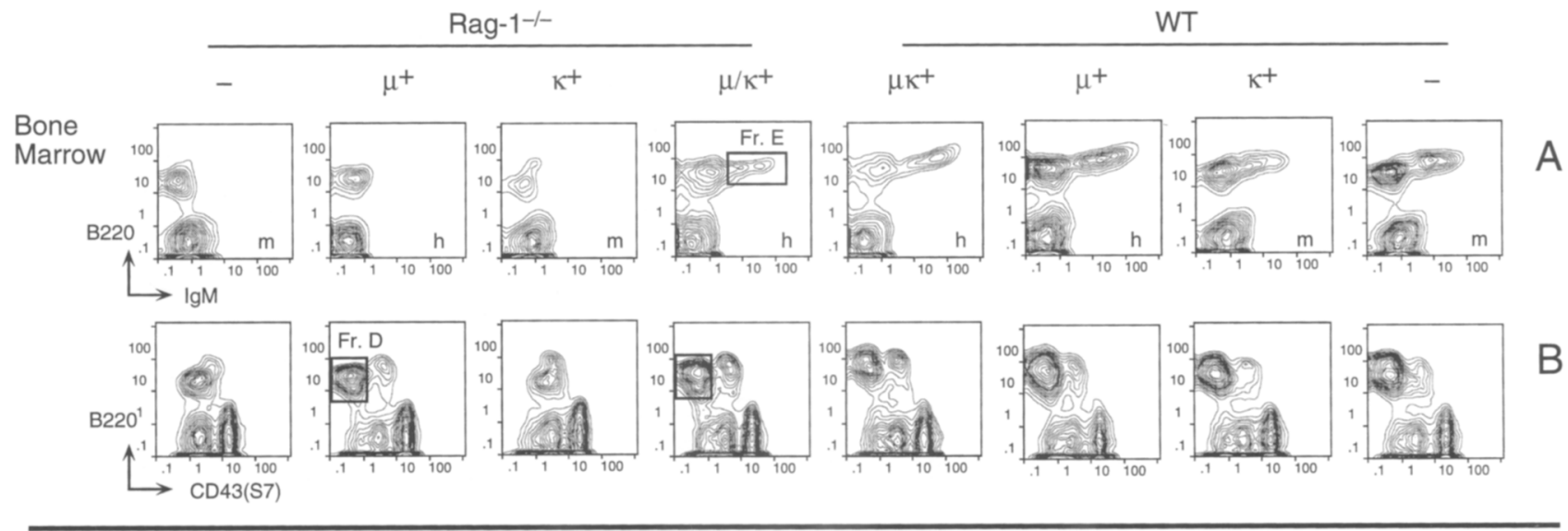

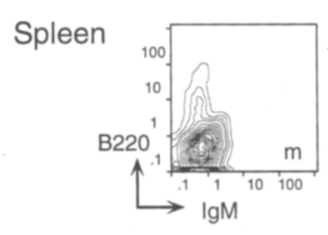

1

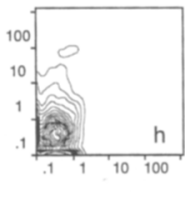

2

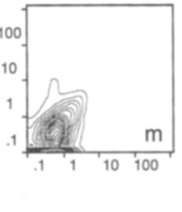

3

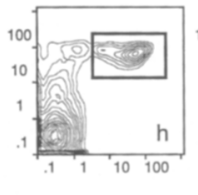

4

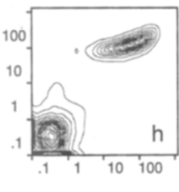

5

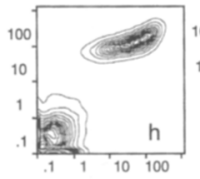

6
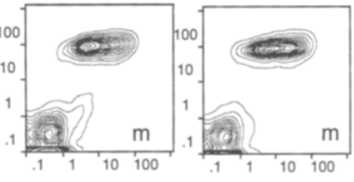

7

Figure 2. FACS analysis of the B-cell lineage in $\mu, \kappa$, and $\mu+\kappa$ transgenic mice. BM and splenic lymphocytes isolated from wild-type (WT), Rag- $1^{-}$, and mice transgenic for rearranged transgenes expressing the membrane form of a human $\mu \mathrm{HC}(\mu)$, or a murine $\kappa L C(\kappa)$, or both $(\mu+\kappa)$, were resolved by four-color analysis for surface expression of B220/CD45R, CD43/S7, IgM, and HSA/30F1 (the latter is not shown) (Hardy et al. 1991). In lanes 1, 3, and 7, IgM refers to the murine (m) form, whereas in lanes 2, 4, 5, and 6, IgM refers to the human (h) transgenic protein. The human transgene encodes the membrane form of $\mu \mathrm{HC}$ and is regulated by the IgH intronic enhancer (Nussenzweig et al. 1987). The murine $\kappa L C$ transgene was isolated from the MOPC 21 myeloma and is regulated by the $\kappa$ intronic enhancer (Brinster et al. 1983).

$\mathrm{IgM}^{+} \mathrm{B}$ cells expressed high levels of HSA (data not shown) and had only a modest response to lipopolysaccharide (LPS) stimulation (see below). In contrast, B-cell differentiation and maturation in the $\mathrm{wt} / \mu \mathrm{k}$ mice more closely resembled the wild-type profile (Fig. 2, A/B/C8 and see below), although the total number of $\mathrm{B} 220^{+}$cells in the $B M$ is reduced. To examine whether a natural pair of $\mathrm{HC}$ and $\mathrm{LC}$ transgenes would provide complete reconstitution, a different series of $\mathrm{Rag}-\mathrm{1}^{-} / \mathrm{IgM}^{+}$mice were generated.

\section{B-cell development in Rag-1- mice expressing an anti-H-2Kk $D^{k}$ class I antibody}

The new parental lines carried murine transgenes encoding an anti-H-2 ${ }^{\mathrm{k}}$ major histocompatibility (MHC) class I antibody $(\mathrm{IgM} / \mathrm{IgD})$ that recognizes $\mathrm{K}^{\mathrm{k}}$ with moderate affinity, $\mathrm{K}^{\mathrm{b}}$ weakly and fails to bind to $\mathrm{H}-2 \mathrm{~K}^{\mathrm{d}}$ expressing cells (Nemazee and Bürki 1989a; Russell et al. 1991). To determine the ability of the anti- $\mathrm{H}-2^{\mathrm{k}}$ antibody to reconstitute the Rag- $1^{-}$phenotype, we generated Rag-1-deficient mice transgenic $\left(\mathrm{Tg}^{+}\right)$for the anti- $\mathrm{H}-2^{\mathrm{k} / \mathrm{b}}$ antibody. The specificity of this antibody also allowed us to study the effect of Rag-1 on tolerance induction by providing a deleting $\mathrm{H}-2^{\mathrm{b}}\left({ }^{\mathrm{b}}\right)$ or permissive $\mathrm{H}-2^{\mathrm{d}}\left({ }^{\mathrm{d}}\right)$ MHC class I haplotype. An extensive analysis of the B-cell fractions in $\mathrm{Tg}^{+}$wild-type or Rag-1 ${ }^{-}$mice is presented in Figure 3.
In the permissive Rag- $1^{-} / \mathrm{Tg}^{+} /{ }^{\mathrm{d}}$ mice, the $\mathrm{BM}$ was characterized by a lack of cells intermediate between the arrested pro-B cells of fraction $\mathrm{C}$ and fraction $\mathrm{E}$ cells, suggesting a transgene-driven acceleration of development (Fig. 3, cf. A/B4, with A/B1). In these mice, mature $B$ cells extensively populated the periphery and expressed high levels of the transgene (Fig. 3, C4). Additionally, both $\operatorname{IgM}^{+}$and $\operatorname{IgD}^{+}$cells were generated (data not shown). Thus, the anti- $\mathrm{H}-2^{\mathrm{k}}$ transgenic antibody directed B-cell lineage development differently from the $\mu \kappa$ hybrid receptor (cf. Fig. 3, A/B3/4 with Fig. 2, A/B4/ 5) allowing reconstitution to the mature B-cell stage. A similar phenotype was observed when the anti-H-2 ${ }^{k}$ transgene was expressed in the wild-type background (Fig. 3, A/B/C2), in accordance to previous analyses (Nemazee and Bürki 1989a,b).

To examine whether MHC-mediated clonal deletion operates in the Rag-1 - background, Rag- $1^{-} / \mathrm{Tg}^{+} / \mathrm{b}$ mice were generated. In these mice, no surface IgM was detected on the predominant $\mathrm{B} 220^{\text {high }}$ subpopulation of the $\mathrm{BM}$ and these cells failed to proceed to the $\mathrm{B} 220^{\text {bright }}$ stage (Fig. 3, A/B5). The absence of surface IgM ${ }^{+}$cells was also evident in the spleen where instead a novel subpopulation of $3220^{+} / \mathrm{IgM}^{-} / \mathrm{IgD}^{-}$cells could be detected (Fig. 3, C5). Thus, negative selection operated efficiently in the absence of Rag-1. Similarly, expression of the transgenic antibody in the $\mathrm{wt} / \mathrm{H}-2^{\mathrm{b}}$ milieu led to 

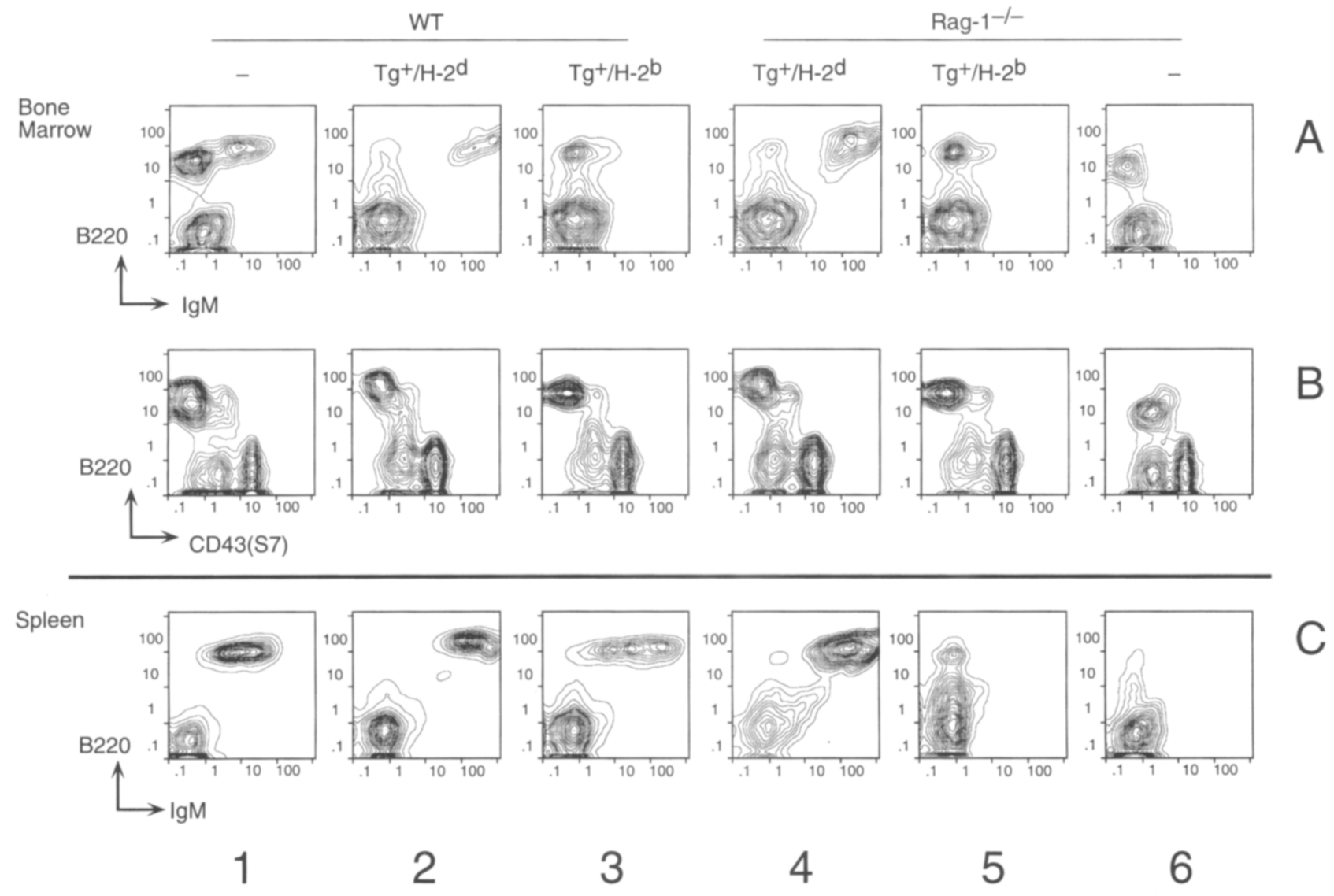

Figure 3. FACS analysis of B-cell development in Rag-1-deficient mice transgenic for an anti-H-2 ${ }^{\mathrm{k}} \mathrm{MHC}$ class I antibody (clone 3-83). Similarly to Fig. 1, bone marrow (BM) or splenic (SPL) B cells were resolved by four-color analysis for the surface markers B220, IgM, and CD43 and HSA (not shown). Genotypes were wild-type (WT), Rag-1 null (Rag-1 ${ }^{-}$), transgenic for an anti- $\mathrm{H}-2^{k}$ antibody (Tg ${ }^{+}$) in either the deleting $\left(\mathrm{H}-2^{\mathrm{b}}\right)$ or nondeleting $\left(\mathrm{H}-2^{\mathrm{d}}\right)$ MHC class I haplotype. The heavy-chain transgenic genomic locus encodes the splicing variants for membrane and secreted $\operatorname{IgH}$ forms of both $\mathrm{C} \mu(\operatorname{IgM})$ and $\mathrm{C} \delta$ (IgD), in their natural configuration (Russell et al. 1991). The homologous light chain is encoded by its corresponding genomic fragment. The transgenes are transcriptionally regulated in part by their respective intronic and $3^{\prime}$ enhancers and are cointegrated within the same chromosomal site. Therefore, it would be expected that onset of $\kappa$ transcription is regulated in part by the $\mathrm{IgH}$ enhancers and vice versa.

complete elimination of all self-reactive B-cells in the $\mathrm{BM}$ and consequently to very low levels of $\mathrm{IgM}^{+}$cells (Fig. 3, A3). However, a high percentage of $\mathrm{IgM}^{+}$cells appeared in the spleens of these mice (Fig. 3, C3). This population was completely eliminated in the Rag-1 ${ }^{-}$ background (Fig. 3, C5) suggesting that these $\mathrm{IgM}^{+}$cells were generated by virtue of endogenous rearrangements (Tiegs et al. 1993).

\section{Transcriptional analysis of B-cell-specific} markers in transgenic mice

The relative homogeneity of the arrested BM cell populations in the Rag-1 ${ }^{-}$background provided an opportunity to examine the properties of these cells. Initially, steady-state mRNA levels of certain lymphoid markers were determined using reverse transcriptase (RT)-PCR to quantitatively amplify specific transcripts (Schlissel and Baltimore 1989). The loci analysed included the $\mathrm{IgH}$ locus transcript $\mu$, which persists throughout B-cell de- velopment; the germ-line IgH transcript $\mu^{\circ}$, which is expressed only in $D$-to- $J$ recombining pro-B cells; and the LPS-inducible germ-line $\kappa L C$ transcript $\kappa^{\circ}$ (see Schlissel et al. 1991b and references therein). No significant effects were seen in a wild-type background. As might have been expected from the phenotypic data, the $\mu$ transgene perturbed gene expression of the Rag-1 ${ }^{-}$cells but the $\kappa$ gene had no effect (Fig. 4). Transcript $\mu^{\circ}$ was expressed in the Rag-1- BM B cells and remained constant irrespective of the presence of the transgenic $\mu$ protein (Fig. 4). In contrast, transcript $\kappa^{\circ}$ was expressed at low levels in the pro-B-cell stage (Rag-1 $\left.{ }^{-}\right)$, but assumed high levels in the presence of the transgenic $\mu$ protein and remained at high levels despite the coexpression of the transgenic $\kappa$ protein (Fig. 4, $\kappa^{\circ}$ lanes 5,6,7,8). Transcription of the surrogate light-chain molecule $\lambda 5$ was high in Rag-1 - cells and decreased markedly in the presence of $\mu$ (Fig. 4, $\lambda 5$ lanes 5-8). Thus, in the transition from fraction $C$ to $D, \mu$ allows the up-regulation of $\kappa^{\circ}$ and down-regulation of $\lambda 5$ transcripts. In the same series 


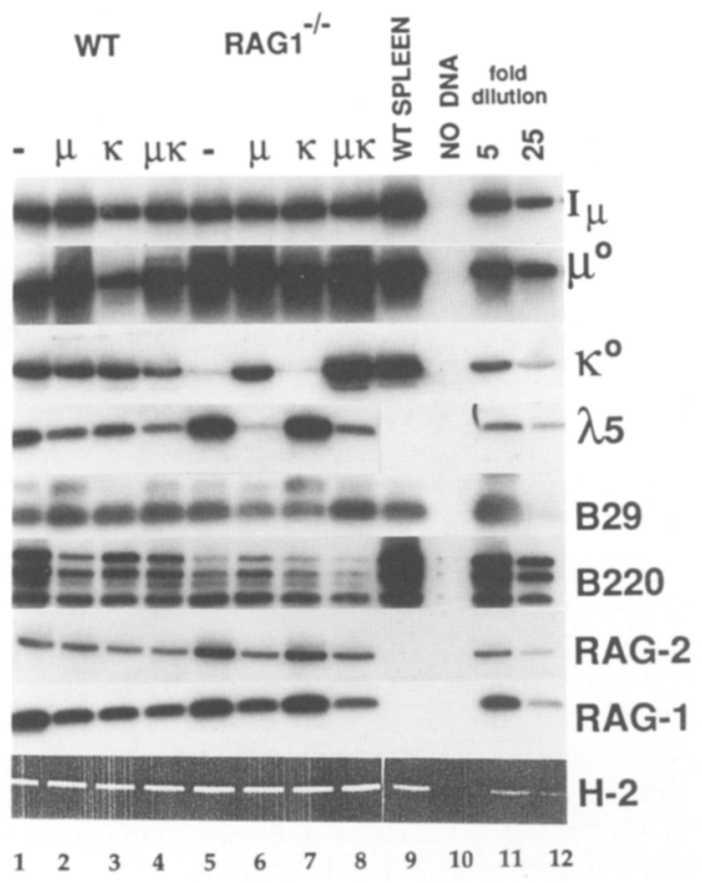

Figure 4. Transcriptional analysis of B-cell-specific markers in BM cells derived from human $\mu$, mouse $\kappa$, and human $\mu$ plus mouse $\kappa$ (hybrid receptor) transgenic mice. Cytoplasmic RNA was isolated from BM and used as a template for cDNA synthesis using random oligonucleotides. The cDNA products were analyzed by PCR using primers specific for the immunoglobulin loci germ-line transcripts $I \mu, \mu^{\circ}$, and $\kappa^{\circ}$, (Schlissel et al. 1991b and references therein), the surrogate light chain molecule $\lambda 5$, the immunoglobulin receptor-associated molecule B29, the B-cell-specific isoform of the surface marker B220, transcripts of Rag- 1 and Rag-2 and, finally, the MHC class I transcript, which represents a ubiquitously expressed mRNA species. The final PCR products were detected by Southern blot hybridization except for the H-2 transcript, which is shown as a photograph of an ethidium bromide-stained gel. (Lanes 1-4) Genotypes. (Lane 1) No transgene $(-1$; (lane 2) transgene $\mu$ (human $\mu$ ); (lane 3) transgene $\kappa$ (mouse $\kappa$ ); (lane 4) transgene $\mu+\kappa$ (human $\mu$ plus mouse k) all in a wild-type background; (lanes 5-8) the same order of transgenic genotypes on a Rag-1 ${ }^{-}$background; (lane 9) wildtype spleen; (lane 10) no cDNA; (lanes 11,12) products from dilutions of the wild-type spleen RNA $11 / 5$ and $1 / 25$, respectively) except in four cases: For the RAG-1 and RAG-2 products, lanes 11 and 12 represent dilutions of the RAG-1 $1^{-1-}$ BM sample; lanes 11 and 12 of $\lambda 5$ represent dilutions of the wild-type BM sample. For the B29 product, because of a loading error, lane 11 corresponds to wild-type spleen and lane 9 shows the fivefold dilution of the sample. The Rag-1 primers amplify transcripts initiated $5^{\prime}$ to the disruption of the Rag-1 locus by the PGK neo gene.

of assays, the steady-state levels of transcripts B220, I $\mu$, and B29 remain unchanged among the Rag- ${ }^{-}$, wildtype, or transgenic BM populations (Fig. 4). In contrast, Rag-1 and Rag-2 transcripts were decreased in the presence of the transgenes but remained easily detectable.

\section{Stromal independence of reconstituted BM populations}

Early stages of lymphoid development are characterized by the interdependence of lymphoid progenitors and stromal epithelial cells (von Gaudecker 1986; van Ewijk 1991; Dorshkind 1990). Direct contact is required for early B-cell progenitor growth and survival, but secreted lymphokines, particularly interleukin-7 (IL-7), are sufficient to allow later cells to proliferate (Lee et al. 1989; Era et al. 1991; Hardy et al. 1991). The pro-B BM cell population (fractions $B$ and C) proliferates selectively on a stromal cell layer (Hardy et al. 1987, 1991). To study the growth properties of these $\mathrm{B} 220^{\text {dull }} / \mathrm{CD} 43^{+}$populations derived from $\mathrm{Rag}-1^{-}$and $\mathrm{Rag}-1^{-} / \mu$ transgenic mice, they were purified by FACS sorting and cultured either directly on FLST2 fetal liver stromal epithelial cells or in a diffusion chamber to prevent direct contact with the stroma (Hardy et al. 1991). Cells were harvested after 4 days and counted for cell recovery. Wild-type pro-B cells proliferated without stromal support because they matured in culture to a contact independent phenotype (Fig. 5). In contrast, Rag- ${ }^{-}$pro-B cells proliferated on FLST2, as well as wild type, but did not grow in a diffusion chamber, indicating their absolute and continued contact dependence. However, expression of the transgenic $\mu$ at the pro-B/pre-B-cell stage was sufficient to alleviate stromal dependence. The Rag- $1^{-} / \mu$ cells became contact independent and proliferated similarly to wild-type cells in the absence of any direct contact with FLST2 (Fig. 5), indicating that this pro-B-cell population contains a fraction of cells committed to differentiate from fraction $\mathrm{C}$ to fraction $\mathrm{D}$.

\section{Functional analysis of the transgenic peripheral lymphocytes}

The simultaneous introduction of rearranged $\mu$ and $\kappa$ transgenes in the Rag-1 ${ }^{-}$genotype produced an overt

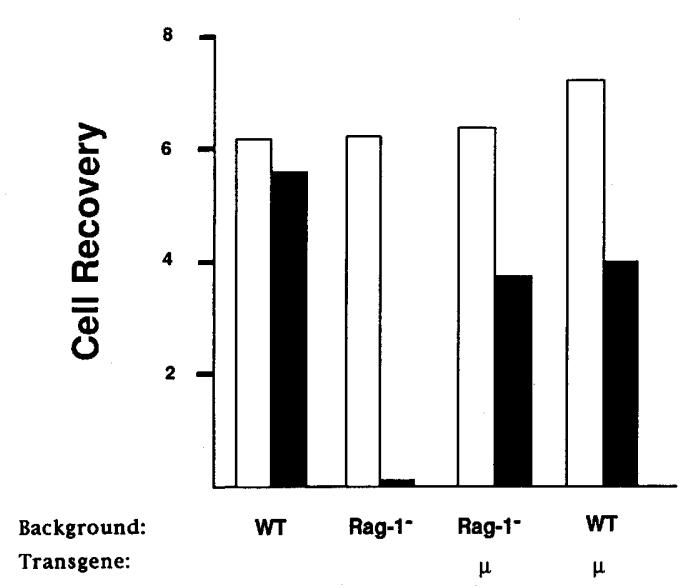

Figure 5. Stromal cell dependence of growth of sorted pro-B $\mathrm{BM}$ cells. $\mathrm{B} 220^{\mathrm{low}} / \mathrm{CD} 43^{+} / \mathrm{HSA}^{+}$cells were isolated from the $B M$ of mice of the indicated genotype and cultured either directly on the FLST2 stromal cell layer (Hardy et al. 1987) or in a diffusion chamber that prevents direct contact with stroma (Hardy et al. 1991). Cell viability was determined 4 days after cultures were established and is shown as fold increase. Genotypes are indicated below each bar. (Open bar) FLST2 contact; (solid bar) diffusion chamber. 
shift in the differentiation of the arrested BM cells and enabled their exit to the periphery (Fig. 2, 4C, and Fig. 3, $4 \mathrm{C})$. To study the response of the reconstituted peripheral lymphocyte cells to external stimuli, splenic B lymphocytes were induced with LPS. Cells from wild-type or Rag $-1-/ \mathrm{Tg}^{+} /{ }^{\mathrm{d}}$ mice readily responded to stimulation by LPS (Fig. 6). Rag- $1^{-} / \mu$ K splenic B cells, however, although variable, showed a reduced proliferation in response to LPS (Fig. 6), consistent with their lack of full maturation.

Subsequently, peripheral lymphocytes were tested for their ability to respond to cross-linking by anti-IgM, as measured by intracellular $\mathrm{Ca}^{2+}$ release (Fig. 7). Upon treatment, lymphocytes transgenic for either anti-H-2 ${ }^{k}$ or $\mu \kappa$ immunoglobulin receptors expressed in a wildtype background, showed a clear $\mathrm{Ca}^{2+}$ release signal (Fig. $7 \mathrm{~b}, \mathrm{e})$. A similar response was observed in Rag- $1^{-}$splenic lymphocytes that have been reconstituted with the anti$\mathrm{H}-2^{\mathrm{k}}$ transgenic receptor (Fig. $7 \mathrm{f}$ ). In sharp contrast, however, the $\mu \kappa$ hybrid receptor failed to fully induce B-cell maturation in the Rag-1 - genotype, as evidenced by the lack of $\mathrm{Ca}^{2+}$ elevation (Fig. 7c).

The functional status of the reconstituted peripheral lymphocytes was also tested by assaying the phosphorylation of cellular proteins on tyrosine in response to antiIgM (Gold et al. 1990, 1991). The results reiterated the $\mathrm{Ca}^{2+}$ release assays in that the $\mathrm{Rag}-1^{-} / \mathrm{Tg}^{+} /{ }^{\mathrm{d}}$ splenic cells showed augmented protein-tyrosine phosphorylation (Fig. 8a, lanes 7,8) while cells with the hybrid $\mu \mathrm{k}$ receptor were unresponsive (Fig. 8a, lanes 4-6). Finally, the difference between the two receptors in restoring the B-cell lineage of Rag-1- mice was reflected in the greatly

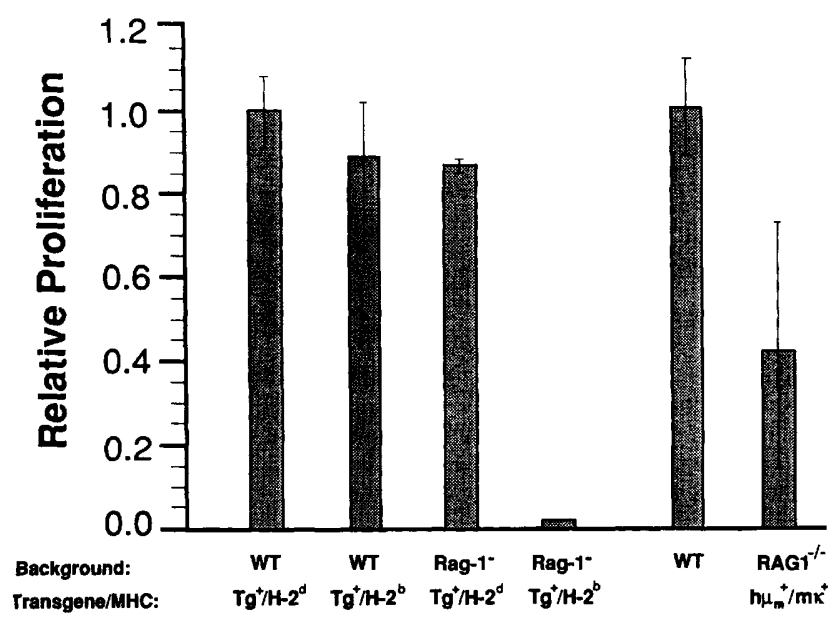

\section{LPS response}

Figure 6. Response of peripheral lymphocytes to LPS stimulation. $\mathrm{B}_{220^{+}}$cells from the spleens of mice of indicated genotypes were isolated by cell sorting and incubated for 4 days in the presence of LPS. Subsequently, cells were harvested and counted. Wild-type cells expanded fivefold during the course of the 4-day incubation (bar labeled WT). decreased levels of $\operatorname{Ig} \alpha$ and $\operatorname{Ig} \beta$ in the splenic lympho-

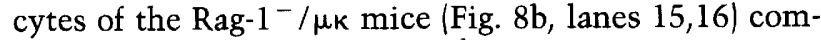
pared with their Rag-1 ${ }^{-} / \mathrm{Tg}^{+} /{ }^{\mathrm{d}}$ counterparts, which expressed levels equal to those of wild type (Fig. 8b, lanes 7,81 .

\section{Discussion}

The total absence of antigen receptor rearrangements in Rag-1-deficient mice emphasizes the indispensable role of Rag-1 in the $V(D) /$ recombination process. In normal murine BM, Rag-1 and Rag-2 enable $V(D) /$ recombination to initiate at the transition between fractions $A$ and B (Table 1). Thus, the initial $D$-to- $I_{H}$ rearrangements can be readily observed in fraction $\mathrm{B}$ while fraction $\mathrm{C}$ is characterized by $V_{H}$-to- $D I_{H}$ rearrangements (Hardy et al. 1991; Ehlich et al. 1993). The phenotypes of mice deficient in Rag-1 (this study) and Rag-2 (Shinkai et al. 1992) suggest that in the absence of receptor gene rearrangement, B-cell differentiation is abrogated after cells reach fraction $\mathrm{C}$, as also observed in scid mice (Hardy et al. $1989)$. Given the extensive $V(D) J$ recombinatorial activity in fractions B and C, the ability of Rag-1 ${ }^{-}$and Rag-2 ${ }^{-}$ $\mathrm{BM}$ cells to proceed through these fractions and arrest in $C$ suggests that the two proteins are involved in organizing or executing the $V(D) I$ recombination reaction $(\mathrm{s})$ rather than being stage-specific regulators of lymphoid development.

The mere expression of a functional immunoglobulin receptor allows complete reconstitution of the B-cell lineage in the Rag- $1^{-}$background, implying that the lack of Rag-1 activity does not result in the absence of any developmental events that are crucial for B-cell differentiation. Similarly, the expression of a functional TCR in Rag-1- or Rag-2-deficient mice allows complete reconstitution of the T-cell lineage in these mice (Mombaerts et al. 1992b; Shinkai et al. 1993; E. Spanopoulou, C.J. Roman, W. van Ewijk, R. Hardy, P. Corbella, C. Mamoclouki, D. Moschofidis, L. Simpson, L.M. Corcoran, D. Kioussis, and D. Baltimore, in prep.). Additionally, the ability of the self-reactive B cells generated in the Rag$1^{-} / \mathrm{Tg}^{+} / \mathrm{b}$ mice to undergo negative selection suggests that Rag-1 is not required for this process. The complete reconstitution of the B-cell lineage in the $\mathrm{Rag}-1^{-} / \mathrm{Tg}^{+} /{ }^{d}$ mice suggests that Rag-1 is not involved in the recombination of any as-yet-unidentified loci that could be critical to immunocyte differentiation. Finally, the lack of Rag-1 expression does not alter the expression of Rag$2, \lambda 5, V_{\text {preB }}, C D 43, H S A, B P-1$, or germ-line immunoglobulin transcripts (this study; Mombaerts et al. 1992a; Shinkai et al. 1992). Thus, the only identified role of Rag-1 and Rag-2 in the lymphoid lineage is to ensure $V(D) /$ rearrangement of the antigen receptor loci.

\section{Expression of the membrane form of $\mu$ in the Rag- $1^{-} / \mu$ mice}

Introduction of a functional $\mu \mathrm{HC}$ transgene, encoding the membrane-bound form, into the Rag- $1^{-}$genotype enables the developmental transition of Rag-1- cells 

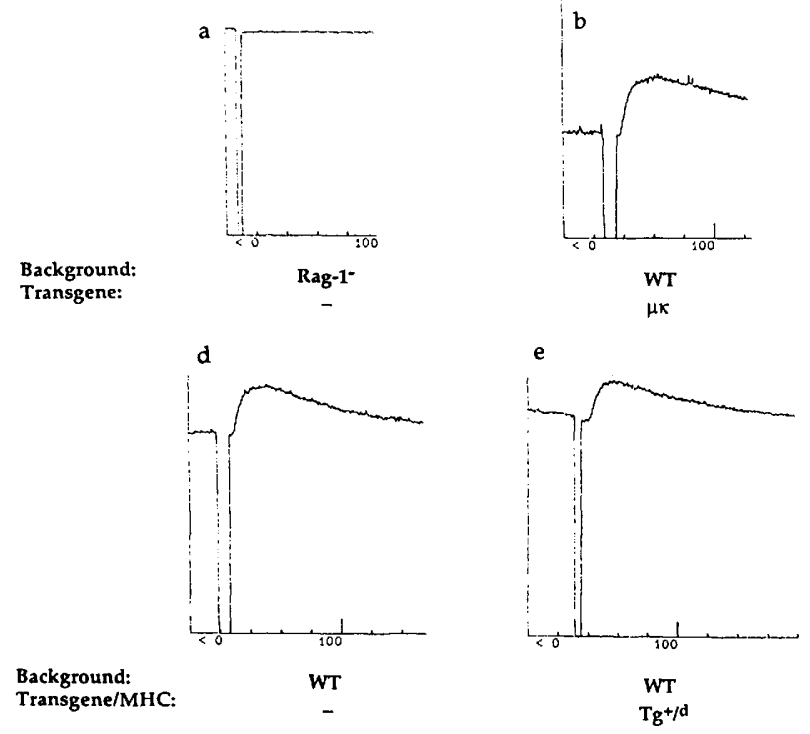

from the pro-B- to the pre-B-cell stage, although no transgenic surface $\mu$ could be detected by FACS analysis. A similar phenotype has been described previously in the $s c i d / \mu$ transgenic mice, in which BM B cells proceed to the small pre-B-cell stage, whereas, no surface $\mu$ could be detected by FACS (Hayashi et al. 1990; Reichman-Fried et al. 1990, 1993). This could be the result of limitations in the level of detection by FACS . Low-level surface expression of the transgenic $\mu$ in $\mathrm{Rag}^{-1} \mathrm{I}^{-} / \mu$ mice has
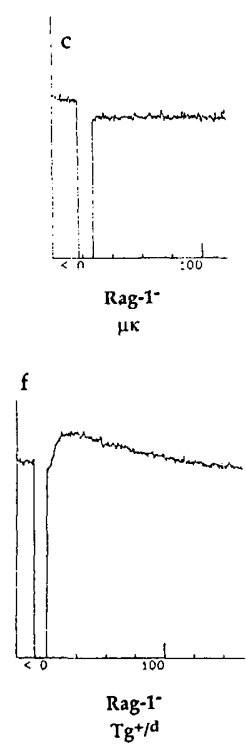

Figure 7. Mobilization of intracellular $\mathrm{Ca}^{2+}$ following engagement of surface IgM. Splenic lymphocytes were isolated from mice of the indicated genotype, loaded with Indo-1, and subjected to IgM cross-linking with either anti-human $\mu$ or anti-mouse $\mu$ [both $F\left(a b^{\prime}\right)_{2}$ ]. The $y$-axis indicates the intracellular free calcium concentration; time is indicated in seconds on the $x$-axis.

been revealed indirectly by probing for induction of tyrosine phosphorylation activity following the surface engagement of the $\mu$ protein (E. Spanopoulou, C.J. Roman, J. Friedrich, J. Cambier, R.R. Hardy, L.M. Corcoran, and D. Baltimore, in prep.).

The competence of the membrane $\mu \mathrm{HC}$ to alleviate the block imposed by the lack of $V(D) I$ recombination has a close parallel in the T-cell lineage. Introduction of a functional TCR $\beta$ chain into either Rag-1- or Rag-2-

$\mathbf{a}$

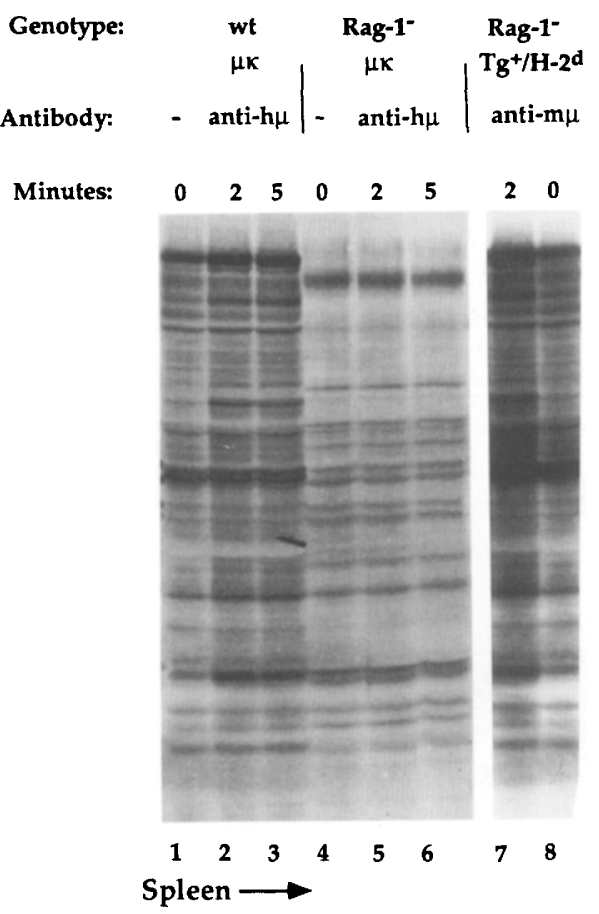

b

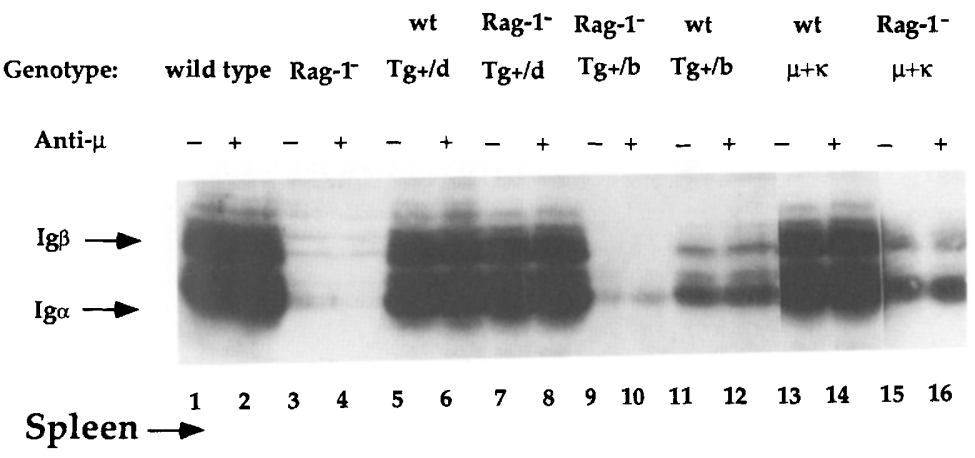

Figure 8. Tyrosine phosphorylation pattern of splenic lymphocytes in response to anti-IgM cross-linking and relative expression of the receptor-asso ${ }^{2}$ ciated proteins $\operatorname{Ig} \alpha$ and $\operatorname{Ig} \beta$. Lymphocytes were isolated from spleens of animals of the indicated genotypes and incubated with the relevant antibody, and total cell extracts were probed by immunoblot analysis using the anti-phosphotyrosine-specific monoclonal antibody 4G10. (a) Splenic lymphocytes from

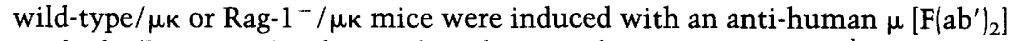
antibody (lanes 1-6), whereas lymphocytes from Rag-1 ${ }^{-} / \mathrm{Tg}^{+} / /^{\mathrm{d}}$ mice were stimulated with an anti-mouse IgM antibody (b 761) (lanes 7,8). Cells were lysed, and the $1 \%$ NP-40 soluble material was subjected to immunodetection by the phosphotyrosine-specific antibody 4G10. (b) Immunoblot analysis of splenic extracts probed with combined antibodies against $\operatorname{Ig} \alpha$ and $\operatorname{Ig} \beta .1+\mid \operatorname{Ig} M$ cross-linking. 
deficient scid mice enables progression of the $\mathrm{CD}^{-1} /$ $\mathrm{CD} 8{ }^{-}$cells to the $\mathrm{CD} 4^{+} / \mathrm{CD} 8^{+}$stage and expression of relatively small amounts of the $\beta$ chain on the surface along with the CD3 auxiliary molecules $\gamma \delta \epsilon$ but not $\zeta$ (Kishi et al. 1991; Mombaerts et al. 1992b; Shinkai et al. 1993). The $\mu \mathrm{HC}$ and the TCR $\beta$ chain are similar in their competence to drive lymphoid differentiation, but one difference is the relative ease of detection of TCR $\beta$ on the surface of pre-T cells. Clearly, a limiting factor for $\mu$ or TCR $\beta$ to emerge on the cell surface is the expression levels of Ig $\alpha \beta$ or CD3 components, respectively (Nakamura et al. 1992, Levelt et al. 1993). An additional factor is suggested by the down-regulation of $\lambda 5$ once a productive $\mu$ chain is expressed (Fig. 4). Thus, at least three components of the "potential" pre-B receptor complex appear to be present at very low levels in the pro-B/preB-cell populations consistent with the low levels of surface $\mu$.

\section{Introduction of membrane-bound IgM in Rag-1 ${ }^{-}$mice}

Ample surface expression of $\mu$ is permitted by the presence of a functional $\kappa \mathrm{LC}$. The regulatory role of the latter is evidenced in the Rag-1-/ ${ }^{-} / \kappa$ mice in which $\mathrm{B}$ cells are not held in fraction $\mathrm{D}$ but proceed to the $\mathrm{B} 220^{\text {high }} / \mathrm{IgM}^{+}$ stage in the BM and acquire competence to emigrate and populate the peripheral lymphoid organs. However, these $\mathrm{IgM}^{+} \mathrm{BM}$ cells fail to reach the $\mathrm{B} 220^{\text {bright }}$ stage observed in normal mice and peripheral transgenic lymphocytes retain a rather immature phenotype failing to respond to external stimuli. At present, we have no experimental explanation for this phenomenon. Both transgenes are particularly successful in pairing with the homologous endogenous chains (Brinster et al. 1983; Nussenzweig et al. 1987). In addition, the same human $\mu \mathrm{HC}$ is functionally active when paired with murine Ig $\alpha$ and Ig (Costa et al. 1992; Sanchez et al. 1993). Expression of the hybrid $\mu+\kappa$ receptor in a wild-type background does not impair B-cell maturation. This is possibly due to the expression of endogenous $\kappa L C s$ that form functional complexes with the transgenic $\mu$. The data suggest that the hybrid receptor can become surface IgM but fails to mediate signaling in the final stages of differentiation. The maturation deficiency of the B cells in Rag-1/ $\mu \kappa$ mice, along with their deficit of $\operatorname{Ig} \alpha$ and $\operatorname{Ig} \beta$, implies that surface IgM is involved in controlling at least two separable steps of B-cell differentiation, one of which is not operative in $\mu \kappa$ mice but is operative in anti-H- ${ }^{k}$ transgenics.

An interesting outcome of the studies on the Rag-1 ${ }^{-} /$ $\mathrm{Tg}^{+} /{ }^{\mathrm{b}}$ mice is the observation that clonal deletion of the self-reactive B lymphocytes takes place equally efficiently in the absence of Rag-1 and T-cell help. Thus, B cells can undergo negative selection without having previously encountered $T$ cells and in the absence of any $V(D) /$ recombination activity. These data support previous suggestions that B-cell tolerance can be achieved in the absence of helper T cells (Bretscher and Cohn 1970; Golan and Borel 1971; Nemazee and Bürki 1989a). The phenotype of the deleting haplotype $\left(\mathrm{Rag}-1^{-} / \mathrm{Tg}^{+} / \mathrm{b}\right)$ is in accordance with the previously reported data that autoreactive B cells are counterselected by deletion (Nemazee and Bürki 1989a) and that both IgM and IgD isotypes of the anti-H-2 ${ }^{k}$ receptor are being deleted (Russell et al. 1991).

The lack of endogenous immunoglobulin in the Rag$1^{-} / \mathrm{Tg}^{+} / /^{\mathrm{b}}$ mice allowed us to examine the surface phenotype of the anti-H-2 $2^{b}$-positive BM cells under deletion conditions. Cells generated in the deleting haplotype reach the $\mathrm{B} 220^{\text {high }}$ stage, whereas a permissive $M H C$ enables the $\mathrm{BM}$ cells to progress to the $\mathrm{B} 220^{\text {bright }}$ stage before they exit to the periphery (Fig. 3, cf. B4 with B5). Thus, elimination of self-reactive cells occurs at the transition from the $\mathrm{B} 220^{\text {high }}$ to the $\mathrm{B} 220^{\text {bright }}$ stage, consistent with previous suggestions about the timing of negative selection (Nemazee and Bürki 1989a,b; Nishimoto et al. 1991; Hartley et al. 1993).

\section{The regulatory role of the $\mu \mathrm{HC}$ membrane form}

A characteristic property of the membrane $\mu$, demonstrated in pre-B-cell lines, is its ability to induce transcriptional activation of the $\kappa$ locus (Iglesias et al. 1991) and subsequently a dramatic increase in the frequency of $V_{\kappa}$-to- $I_{\kappa}$ rearrangements in fraction D (Reth et al. 1987; Hardy et al. 1991; Iglesias et al. 1991; Ehlich et al. 1993; Li et al. 1993; Shapiro et al. 1993). This property is consistent with the model that transcription and recombination of the immunoglobulin loci follow an ordered pattern (Alt et al. 1987; Schlissel and Baltimore 1989; Schlissel et al. 1991a). However, the analysis of Rag-1 ${ }^{-}$ $\mathrm{BM}$ cells revealed that the $\mathrm{k}$ locus is transcribed prior to the production of a $\mu$, albeit at low levels. This discrepancy has also been observed in the $\mu \mathrm{MT}$ mice, in which BM cells show a low frequency of recombination in the $\kappa$ locus despite the lack of any $\mu$ (Kitamura and Rajewsky 1992; Ehlich et al. 1993). Thus, in agreement with previous observations (Blackwell et al. 1989; Kubagawa et al. 1989; Schlissel and Baltimore 1989), our data suggest that the initial low levels of transcription and recombination in the $\kappa$ locus are independent of the presence of the $\mu \mathrm{HC}$. It is possible that initial $\kappa$ transcripts give rise to functional $\kappa$ LCs (Kitamura et al. 1992). In contrast to this early phase, however, elevated $\kappa$ transcription is dependent on $\mu$ as demonstrated by the phenotype of the Rag- $1^{-} / \mu$ BM cells. Therefore, the increase in transcription and frequency of recombination of the $\kappa$ locus in fraction $D$ appears to be a regulatory property of $\mu$.

The transcriptional analysis of the Rag-1 and Rag$1^{-} / \mu$ BM populations revealed the additional ability of $\mu$ to promote the down-regulation of $\lambda 5$ in fraction $\mathrm{D}$. This property of $\mu$ is in accord with the decreased levels of $\lambda 5 / \mathrm{V}_{\text {preB }}$ observed in the transition from fractions $C$ to $D$ in the BM of normal mice ( $\mathrm{Li}$ et al. 1993) but is discrepant with previous observations on pre-B-cell lines (Iglesias et al. 1991; Kudo et al. 1992).

The regulatory role of $\mu$ at the pre-B cell stage is emphasized by the competence of the Rag- $1^{-} / \mu$ pro-B/pre-B cells to proliferate in the presence of IL-7 but independently of attachment to the BM stroma. These data are 
similar to observations from wild-type and scid BM cells, indicating that early pro-B cells proliferate only in contact with the BM stroma but the expression of a functional $\mu$ at the transition from fraction $C$ to $C^{\prime}$ enables entrance to the second, IL-7 responsive phase (Hayashi et al. 1990; Era et al. 1991; Reichman-Fried et al. 1993).

In conclusion, the phenotype of the Rag- $1^{-/ \mu}$ mice underlines the multiple regulatory functions of membrane $\mu$ at the pre-B cell stage. In separate studies we were able to show that $\mu$ emerges on the surface of these cells albeit at low levels (E. Spanopoulou, C.J. Roman, J. Friedrich, J. Cambier, R.R. Hardy, L.M. Corcoran, and D. Baltimore, in prep.). Membrane $\mu$ is present at high levels in the cytoplasm, complexed to SLC or $\kappa$ moieties (Pillai and Baltimore 1987; Takemori et al. 1990; Lassoued et al. 1993), apparently retained in the endoplasmic reticulum by BiP protein (Häas and Wabl 1983). Therefore, the question remains whether development of pre-B cells is directed by the $\mu$ resident on the cell surface and/or its cytoplasmic form and what is the exact functional significance of low levels of surface $\mu$. A similar question is raised about the functional importance of low levels of TCR $\beta$ homodimers on the surface of pro-T cells (Mombaerts et al. 1992b; Shinkai et al. 1993).

The above studies show that B-cell development pauses at certain checkpoints, being dependent on the expression of the checkpoint determinant for transition to the next stage. Expression of these determinants, i.e., the membrane forms of $\mu$ or $\mu \kappa$, allows progression through the checkpoints and further differentiation.

\section{Materials and methods}

Targeted disruption of Rag-1

The mouse Rag-1 gene was isolated from transfected NIH-3T3 fibroblasts expressing Rag-1 activity (Schatz et al. 1989). The targeting vector carried genomic Rag-1 sequences $17.6 \mathrm{~kb}$ spanning the coding region) from the upstream EcoRV site to a $3^{\prime}$ $X b a I$ site). A cassette containing the $\mathrm{PMCl}$ neomycin-resistance gene under the control of the PGK promoter, and carrying a polyadenylation signal (see Corcoran et al. 1993) was inserted into an internal EcoRV site in the Rag-1-coding sequence. The PGK neo insertion generated a frameshift mutation. A thymidine kinase cassette was inserted at the $5^{\prime}$ end of the targeting vector to select against random integration.

Il embryonic stem (ES) (SVJ129) cells were cultured on $\gamma$-irradiated (20Gy) primary embryonic (Neo resistant) fibroblasts as described (Corcoran et al. 1993). Twenty micrograms of linearized targeting vector was transfected into $8 \times 10^{6}$ ES cells by electroporation $(400 \mathrm{~V}, 25 \mathrm{mF})$. Selection was initiated $48 \mathrm{hr}$ later in the presence of $400 \mu \mathrm{g} / \mathrm{ml}$ of G418 with or without FIAU (0.2 mm). Resistant colonies were picked 8 days after selection, and homologous recombinants were identified by Southern analysis. Approximately 1/25 doubly resistant clones contained successful disruptions of the Rag-1 allele.

ES cell clones containing one RAG-1 mutant allele were injected into blastocysts of $\mathrm{C} 57 \mathrm{BL} / 6$ mice and transplanted into the uteri of foster mothers. Several of the derived chimeric mice transmitted the mutant allele to their offspring, which were further backcrossed to establish mice homozygous for the mutation. Neonatal Rag-1 $1^{-1-}$ mice were genotyped by Southern analysis to reveal a Mendelian pattern of transmission of the Rag-1 null allele.

\section{Flow cytometry analysis, sorting, and culture conditions}

Preparation of single cell suspension cells from the BM and subsequent immunostaining and FACS analysis, as well as sorting and culturing of the cells when required, were performed as described (Hardy et al. 1991) using the identical reagents. The human transgenic heavy chain was identified by an anti-human $\mu$ antibody (clone 145-8, Becton Dickinson), subsequently biotin conjugated.

\section{RNA preparations and PCR assays}

Preparation of total cellular RNA, reverse transcription, and subsequent analysis of the cDNA products by PCR were performed as described (Schlissel et al. 1991b) using the identical primers.

\section{LPS stimulation proliferation assay}

$\mathrm{B} 220^{+}$cells from spleens of mice of indicated that genotypes were isolated by cell sorting and plated at $10^{6}$ cells $/ \mathrm{ml}(100$ $\mu \mathrm{l} /$ well of a 96 -well plate) in RPMI-1640 medium (supplemented with $5 \times 10^{-5} \mathrm{M} 2$-mercapoethanol and $10 \%$ fetal calf serum) containing $10 \mu \mathrm{g} / \mathrm{ml}$ of LPS (Sigma). After 4 days, cells were harvested and counted.

\section{Culturing on FLST2 stroma cells}

Experimental conditions were as described previously (Hardy et al. 1987, 1991). Experimental cultures on FLST2 were carried out in 24-well plates (Nunc), using $1 \mathrm{ml}$ of standard medium. Cultures were also performed by inserting diffusion chambers ("Millicell", Millipore Corp.) into wells containing pre-established FLST2 layers. Typically, $1 \times 10^{4}$ to $5 \times 10^{4}$ sorted cells were placed in each well.

\section{$\mathrm{Ca}^{2+}$ mobilization assays}

Loading of the cells with Indo-1 and measurements of intracellularly released $\mathrm{Ca}^{2+}$ were essentially performed as described (Costa et al. 1992). Indo-1-loaded cells were incubated at $37^{\circ} \mathrm{C}$ for $5 \mathrm{~min}$, and transferred to a fluorimeter cuvette, and antibody was added to a final concentration of $15 \mu \mathrm{g} / \mathrm{ml}$.

\section{IgM cross-linking, preparation of cytoplasmic extracts, and Western analysis}

Splenic lymphocytes were isolated without red blood cells and cultured at a density of $5 \times 10^{6} / \mathrm{ml}$ in RPMI $/ 10 \% \mathrm{FCS} / \beta$-mercaptoethanol at $37^{\circ} \mathrm{C}$ for $30 \mathrm{~min}$ prior to the addition of antibody. Anti-mouse Fab (Jackson Laboratory) or a rabbit polyclonal anti-human (Southern Biotechnology) was added to a final concentration of $25 \mu \mathrm{g} / \mathrm{ml}$, and the suspended cells were incubated further for $5 \mathrm{~min}$. Cross-linking was terminated by the addition of $12 \mathrm{ml}$ of ice-cold PBS containing $1 \mathrm{mM}$ orthovanadate, and the pelleted cells were lysed in $20 \mathrm{mM} \mathrm{HEPES} \mathrm{(pH}$ $7.9), 100 \mathrm{~mm} \mathrm{KCl}, 300 \mathrm{~mm} \mathrm{NaCl}, 1 \% \mathrm{NP}-40,1 \mathrm{~mm}$ orthovanadate, $1 \mathrm{~mm} \mathrm{NaF}$, and $10 \mathrm{~mm}$ EDTA in the presence of several protease inhibitors. After sonication, extracts were separated on an $8 \%$ polyacrylamide gel and transferred onto nitrocellulose using $10 \mathrm{~mm}$ CAPS (pH 11.0), and $20 \%$ methanol. Filters were incubated in TBST $(10 \mathrm{~mm}$ Tris at $\mathrm{pH} 8.0 ; 150 \mathrm{mM} \mathrm{NaCl} ; 0.05 \%$ Tween 20) and blocked with either $2 \%$ BSA (for the anti-phos- 
photyrosine antibody) or $2 \%$ milk for the Ig $\alpha$ and $\operatorname{Ig} \beta$ antibodies, incubated with the primary antibodies overnight at $4^{\circ} \mathrm{C}$, washed several times, incubated with the secondary antibodies for 30 min, washed again, and developed by alkakine phosphatase (Promega) or chemilluminescence (Amersham). The anti-phosphotyrosine monoclonal antibody $4 \mathrm{G} 10$ was purchased from UBI.

\section{Acknowledgments}

E.S. is grateful to Dr. En Li for providing the Jl ES cells and guidance into the ES cell technology. Dr. Ursula Storb generously provided the MOPC $21 \kappa$ transgenic line. We thank Dr. Tyler Jacks for advice. E.S. acknowledges the help of Thais Costa and Mercedes Sanchez on the $\mathrm{Ca}^{2+}$ release assays and Dr. Yongwon Choi for computer aid. E.S. was initially supported by an EMBO long-term fellowship, and is currently supported by Cancer Research Institute. C.R. is the recipient of a Damon Runyon-Walter Winchell Cancer Research Fund Fellowship. L.M.C. and M.S.S. acknowledge the support of Cancer Research Institute Investigator Awards. This work was supported by $\mathrm{Na}$ tional Institutes of Health grant CA54162 to D.B.

The publication costs of this article were defrayed in part by payment of page charges. This article must therefore be hereby marked "advertisement" in accordance with 18 USC section 1734 solely to indicate this fact.

\section{References}

Alt, F.W., G.D. Yancopoulos, T.K. Blackwell, C. Wood, E. Thomas, M. Boss, R. Coffman, N. Rosenberg, S. Tonegawa, and D. Baltimore. 1984. Ordered rearrangement of immunoglobulin heavy chain variable region segments. EMBO $J$. 3: 1209-1219.

Alt, F., T. Blackwell, and G. Yancopoulos. 1987. Development of the primary antibody repertoire. Science 238: 1079-1087.

Blackwell, T.K., B.A. Malynn, R.R. Pollock, P. Ferrier, L.R. Covey, G.M. Fulop, R.A. Phillips, G.D. Yancopoulos, and F.W. Alt. 1989. Isolation of scid pre-B cells that rearrange kappa light chain genes: formation of normal signal and abnormal coding joins. EMBO I. 8: 735-742.

Bosman, M.J. and A.M. Carroll. 1991. The SCID mouse mutant: Definition, characterization, and potential uses. Annu. Rev. Immunol. 9: 323-350.

Bossy, D., J. Salamero, D. Olive, M. Fougereau, and C. Schiff. 1993. Structure, biosynthesis, and transduction properties of the human $\mu-\psi \mathrm{L}$ complex: Similar behavior of pre-B cells in transducing ability. Int. Immunol. 5: 467-478.

Brandle, D., C. Müller, T. Rülicke, H. Hengartner, and H. Pircher. 1992. Engagement of the T-cell receptor during positive selection in the thymus down-regulates RAG-1 expression. Proc. Natl. Acad. Sci. 89: 9529-9533.

Bretscher, P. and M. Cohen. 1970. A theory of non-self discrimination. Paralysis and induction involve the recognition of one and two determinants on an antigen, respectively. Science 169: 1042-1049.

Brinster, R.L., K.A. Ritchie, R.E. Hammer, R.L. O'Brien, B. Arp, and U. Storb. 1983. Expression of a microinjected immunoglobulin gene in the spleen of transgenic mice. Nature 306: 332-336.

Burnet, F.M. 1959. The clonal selection theory of acquired immunity. (Cambridge University Press), Cambridge, England.

Campbell, K.S., E.J. Hager, R.J. Friedrich, and J.C. Cambier 1991. IgM antigen receptor complex contains phosphoprotein products of B29 and $m b-1$ genes. Proc. Natl. Acad. Sci.
88: 3982-3986.

Cherayil, B.J. and S. Pillai. 1991. The $\omega / \lambda 5$ surrogate immunoglobulin light chain is expressed on the surface of transitional B lymphocytes in murine bone marrow. J. Exp. Med. 173: 111-116.

Clark, E.A. and P.J.L. Lane. 1991. Regulation of human B-cell activation and adhesion. Annu. Rev. Immunol. 9: 97-127.

Corcoran, L.M., M. Karvelas, G.J.V. Nossal, Z.-S. Ye, T. Jacks, and D. Baltimore. 1993. Oct-2, although not required for early B-cell development, is critical for later B-cell maturation and for postnatal survival. Genes \& Dev. 7: 570-582.

Costa, T.E., R.R. Franke, M. Sanchez, Z. Misulovin, and M.C. Nussenzweig. 1992. Functional reconstitution of an immunoglobulin antigen receptor in $\mathrm{T}$ cells. I. Exp. Med. 175: 1669-1676.

Dorshkind, K. 1990. Regulation of hemopoiesis by bone marrow stromal cells and their products. Annu. Rev. Immunol. 8: 111-137.

Ehlich, A., S. Schaal, H. Gu, D. Kitamura, W. Müller, and K. Rajewsky. 1993. Immunoglobulin heavy chain and light chain genes rearrange independently at early stages of B cell development. Cell 72: 695-704.

Era, T., M. Ogawa, S-I. Nishikawa, M. Okamoto, T. Honjo, K. Akagi, J.-I. Miyazaki, and K.-I. Yamamura. 1991. Differentiation of growth signal requirement of B lymphocyte precursor is directed by expression of immunoglobulin. EMBO $J$. 10: $337-342$.

Gilfillan, S., A. Dierich, M. Lemeur, C. Benoist, and D. Mathis. 1993. Mice lacking TdT: Mature animals with an immature lymphocyte repertoire. Science 261: 1175-1178.

Golan, D.T. and Y. Borel. 1971. Nonantigenicity and immunologic tolerance: the role of the carrier in the induction of tolerance to the hapten. I. Exp. Med. 134: 1060.

Gold, M.R., D.A. Law, and A.L. DeFranco. 1990. Stimulation of protein tyrosine phosphorylation by the B-lymphocyte antigen receptor. Nature 345: 810-813.

Gold, M.R., L. Matsuuchi, R.B. Kelly, and A.L. DeFranco. 1991. Tyrosine phosphorylation of components of the B-cell antigen receptors following receptor crosslinking. Proc. Natl. Acad. Sci. 88: 3436-3438.

Häas, I.G. and M. Wabl. 1983. Immunoglobulin heavy chain binding protein. Nature 306: 387-389.

Hardy, R.R., T. Kishimoto, and K. Hayakawa. 1987. Differentiation of B-cell progenitors in vitro: Generation of surface $\mathrm{IgM}^{+}$B-cells, including Ly-1 B cells, from Thy-1- asialoGM1 ${ }^{+}$cells in newborn liver. Eur. J. Immunol. 17: 17691774.

Hardy, R.R., J.D. Kemp, and K. Hayakawa. 1989. Analysis of lymphoid populations in scid mice: Detection of a potential B-lymphocyte progenitor population present at normal levels in scid mice by three color flow cytometry with B220 and S7. Curr. Top. Microbiol. 152: 19-25.

Hardy, R.R., C.E. Carmack, S.A. Shinton, J.D. Kemp, and K. Hayakawa. 1991. Resolution and characterization of pro-B and pre-pro-B cell stages in normal mouse bone marrow. $J$. Exp. Med. 173: 1213-1225.

Hartley, S.B., M.P. Cooke, D.A. Fulcher, A.W. Harris, S. Cory, A. Basten, and C.C. Goodnow. 1993. Elimination of selfreactive B-lymphocytes proceeds in two stages: Arrested development and cell death. Cell 72: 325-335.

Hayashi, S., T. Kunisada, M. Ogawa, T. Sudo, H. Kodama, T. Suda, S. Nishikawa, and S.I. Nishikawa. 1990. Stepwise progression of B lineage differentiation supported by interleukin-7 and other stromal cell molecules. I. Exp. Med. 171: 1683-1695.

Iglesias, A., M. Kopf, G.S. Williams, B. Bühler, and G. Köhler. 
1991. Molecular requirements for the $\mu$-induced light chain gene rearrangement in pre-B cells. $E M B O J$. 10: 2147-2156.

Karasuyama, H., A. Rolink, and F. Melchers. 1993. A complex of glycoproteins is associated with $\mathrm{V}_{\text {preB }} / \lambda 5$ surrogate light chain on the surface of $\mu$ heavy chain-negative early precursor B-cell lines. J. Exp. Med. 178: 469-478.

Kerr, W.G., M.D. Cooper, L. Feng, P.D. Burrows, and L.M. Hendershot. 1989. Mu heavy chains can associate with a pseudolight chain complex $(\psi \mathrm{L})$ in human pre-B cell lines. Int. Immunol. 1: 355-361.

Kishi, H., P. Borgulya, B. Scott, K. Karjalainen, A. Traunecker, J. Kaufman, and H. von Boehmer. 1991. Surface expression of the $\beta \mathrm{T}$ cell receptor (TCR) chain in the absence of other TCR or CD3 proteins on immature T cells. EMBO I. 10: 93100.

Kitamura, D. and K. Rajewsky. 1992. Targeted disruption of $\mu$ chain causes loss of heavy-chain allelic exclusion. Nature 356: 154-156.

Kitamura, D., J. Roes, R. Kühn, and K. Rajewsky. 1991. A B-cell deficient mouse by targeted disruption of the membrane exon of the immunoglobulin $\mu$ chain gene. Nature 350: 423426.

Kitamura, D., A. Kudo, S. Schaal, W. Müller, F. Melchers, and K. Rajewsky. 1992. A critical role of $\lambda_{5}$ in B cell development. Cell 69: 823-831.

Komori, T., A. Okada, V. Stewart, and F.W. Alt. 1993. Lack of N regions of antigen receptor variable region genes of TdTdeficient lymphocytes. Science 261: 1171-1175.

Kubagawa, H., M.D. Cooper, A.J. Carroll, and P.D. Burrows. 1989. Light-chain gene expression before heavy-chain gene rearrangement in pre-B cells transformed by Epstein-Barr virus. Proc. Natl. Acad. Sci. 86: 2356-2360.

Kudo, A., P. Thalmann, N. Sakaguchi, W.F. Davidson, J.H. Pierce, J.F. Kearney, M. Reth, A. Rolink, and F. Melchers. 1992. The expression of the mouse $\mathrm{VpreB} / \lambda 5$ locus in transformed cell lines and tumors of the B lineage differentiation pathway. Int. Immunol. 4: 831-840.

Landau, N.R., D.G. Schatz, M. Rosa, and D. Baltimore. 1987. Increased frequency of $\mathrm{N}$ region insertion in a murine preB-cell line infected with a terminal deoxytransferase retroviral expression vector. Mol. Cell. Biol. 7: 3237-3243.

Lassoued, K., C.A. Nunez, L. Billips, H. Kubagawa, R.C. Monteiro, T.W. LeBien, and M.D. Cooper. 1993. Expression of surrogate light chain receptors is restricted to a late stage in pre-B cell differentiation. Cell 73: 73-86.

Lee, G., A.E. Namen, S. Gillis, L.R. Ellingsworth, and P.W. Kincade. 1989. Normal B-cell precursors responsive to recombinant murine IL-7 (IL-7) and inhibition of IL-7 activity by TGF- $\beta$. J. Immunol. 142: 3875-3883.

Levelt, C.N., R. Carsetti, and K. Eichmann. 1993. Regulation of thymocyte development through CD3. II. Expression of $\mathrm{T}$ cell receptor $\beta \mathrm{CD} 3 \epsilon$ and maturation of the $\mathrm{CD} 4{ }^{+} \mathrm{CD} 8^{+}$ stage are highly correlated in individual thymocytes. I. Exp. Med. 178: 1867-1875.

Li, Y.-S., K. Hayakawa, and R.R. Hardy. 1993. The regulated expression of B lineage associated genes during $\mathrm{B}$ cell differentiation in bone marrow and fetal liver. I. Exp. Med. 178: 951-960.

Ma, A., P. Fisher, R. Dildrop, E. Oltz, G. Rathbun, P. Achacoso, A. Stall, and F.W. Alt. 1992. Surface IgM mediated regulation of RAG gene expression in $\mathrm{E} \mu-\mathrm{N}-m y c \mathrm{~B}$ cell lines. EMBO I. 11: $2727-2734$.

Manz, J., K. Denis, O. Witte, R. Brinster, and U. Storb. 1988. Feedback inhibition of immunoglobulin gene rearrangement by membrane $\mu$ but not by secreted $\mu$ heavy chain. J. Exp. Med. 168: 1363-1370.
Misener, V., G.P. Downey, and J. Jongstra. 1991. The immunoglobulin light chain related protein $\lambda 5$ is expressed on the surface of mouse pre-B cell lines and can function as a signal transducing molecule. Int. Immunol. 3: 1129-1136.

Mombaerts, P., J. Iacomini, R.S. Johnson, K. Herrup, S. Tonegawa, and V. Papaioannou. 1992a. RAG-1 deficient mice have no mature B and T lymphocytes. Cell 68: 869-878.

Mombaerts, P., A.R. Clarke, M.A. Rudnicki, J. Iakomini, S. Itohara, J.L. Lafaille, L. Wang, Y. Ichikawa, R. Jaenisch, M.L. Hooper, and S. Tonegawa. 1992b. Mutations in T-cell antigen receptor genes $\alpha$ and $\beta$ block thymocyte development at different stages. Nature 360: 225-231.

Nakamura, T., H. Kubagawa, and M.D. Cooper. 1992. Heterogeneity of immunoglobulin-associated molecules on human B-cells identified by monoclonal antibodies. Proc. Natl. Acad. Sci. 89: 8522-8526.

Nemazee, D. and K. Bürki. 1989a. Clonal deletion of B lymphocytes in a transgenic mouse bearing anti-MHC class I antibody genes. Nature 337: 562-566.

- $1989 \mathrm{~b}$. Clonal deletion of autoreactive B lymphocytes in bone marrow chimeras. Proc. Natl. Acad. Sci. 86: 80398043.

Nishimoto, N., H. Kubagawa, T. Ohno, G.L. Gartland, A.K. Stankovic, and M.D. Cooper. 1991. Normal pre-B cells express a receptor complex of $\mu$ heavy chains and surrogate light-chain proteins. Proc. Natl. Acad. Sci. 88: 6284-6288.

Nussenzweig, M.C., A.C. Shaw, E. Sinn, D.B. Danner, K.L. Holmes, H.C. Morse III, and P. Leder. 1987. Allelic exclusion in transgenic mice that express the membrane form of immunoglobulin $\mu$. Science 236: 816-819.

Oettinger, M.A., D.G. Schatz, C. Gorka, and D. Baltimore. 1990. RAG-1 and RAG-2, adjacent genes that synergistically activate $V(D) /$ recombination. Science 248: 1517-1523.

Pillai, S. and D. Baltimore. 1987. Formation of disulphide-linked $\mu_{2} \omega_{2}$ tetramers in pre-B cells by the $18 \mathrm{~K} \omega$-immunoglobulin light chain. Nature 329: 172-174.

Reichman-Fried, M., R.R. Hardy, and M.J. Bosma. 1990. Development of B-lineage cells in the bone marrow of scid-scid mice following the introduction of functionally rearranged immunoglobulin transgenes. Proc. Natl. Acad. Sci. 87: 2730-2734.

Reichman-Fried, M., M.J. Bosma, and R.R. Hardy. 1993. B-lineage cells in $\mu$-transgenic scid mice proliferate in response to IL-7 but fail to show evidence of immunoglobulin light chain gene rearrangement. Int. Immunol. 5: 303-310.

Reth, M., E. Petrac, P. Wiese, L. Lobel, and F.W. Alt. 1987. Activation of $V_{\kappa}$ gene rearrangement in pre-B cells follows the expression of membrane-bound immunoglobulin heavychains. EMBO I. 6: 3299-3305.

Rolink, A. and F. Melchers. 1991. Molecular and cellular origins of B lymphocyte diversity. Cell 66: 1081-1094.

Russell, D.M., Z. Dembić, G. Morahan, J.F.A.P. Miller, K. Bürki, and D. Nemazee. 1991. Peripheral deletion of self-reactive B-cells. Nature 354: 308-311.

Sanchez, M., Z. Misuvolin, A.L. Burkhardt, S. Mahajan, T. Costa, R. Franke, J.B. Bolen, and M.C. Nussenzweig. 1993. Signal transduction by immunoglobulin is mediated through $\operatorname{Ig} \alpha$ and $\operatorname{Ig} \beta$. J. Exp. Med. 178: 1049-1055.

Schatz, D., M.A. Oettinger, and D. Baltimore. 1989. The V(D)J recombination activating gene RAG-1. Cell 59: 1035-1048.

Schatz, D., M.A. Oettinger, and M.S. Schlissel. 1992. V(D|J recombination. Molecular biology and regulation. Annu. Rev. Immunol. 10: 359-383.

Schlissel, M. and D. Baltimore. 1989. Activation of immunoglobulin kappa gene rearrangement correlates with induction of germline kappa gene transcription. Cell 58: 1001- 
1007.

Schlissel, M.S., L.M. Corcoran, and D. Baltimore. 1991a. Virally-transformed pre-B cells show ordered activation but not inactivation of immunoglobulin gene rearrangement and transcription. J. Exp. Med. 173: 711-720.

Schlissel, M., A. Voronova, and D. Baltimore. 1991b. Helixloop-helix transcription factor E47 activates germline immunoglobulin heavy-chain gene transcription and rearrangement in a pre-T cell line. Genes \& Dev. 5: 1367-1376.

Shapiro, A.M., M.A. Schlissel, D. Baltimore, and A.L. DeFranco. 1993. Stimulation of $k$-light chain gene rearrangement by the immunoglobulin $\mu$ heavy chain in a pre-B cell line. Mol. Cell. Biol. 13: 5679-5690.

Shinkai, Y., G. Rathbun, K.-P., Lam, E.M. Oltz, V. Stewart, M. Mendelsohn, J. Charron, M. Datta, F. Young, A.M. Stall, and F.W. Alt. 1992. RAG-2 deficient mice lack mature lymphocytes owing to inability to initiate V(D) rearrangement. Cell 68: 855-868.

Shinkai, Y., S. Koyasu, K.-I. Nakayama, K.M. Murphy, D.Y. Loh, E.L. Reinherz, and F.W. Alt. 1993. Restoration of T-cell development in RAG-2 deficient mice by functional TCR transgenes. Science 259: 822-825.

Storb, U. 1987. Transgenic mice with immunoglobulin genes. Annu. Rev. Immunol. 5: 151-174.

Taccioli, G.E., G. Rathbun, E. Oltz, T. Stamato, P.A. Jeggo, and F.W. Alt. 1993. Impairment of V(D)J recombination in double-strand break repair mutants. Science 260: 207-210.

Takemori, T., I. Mizuguchi, I. Miyazoe, M. Nakanishi, K. Shigemoto, H. Kimoto, T. Shirasawa, N. Maruyama, and M. Taniguchi. 1990. Two types of $\mu$ chain complexes are expressed during differentiation from pre-B to mature B cells. EMBO $J$. 9: 2493-2500.

Tiegs, S.L., D.M. Russell, and D. Nemazee. 1993. Receptor editing in self-reactive bone marrow B-cells. I. Exp. Med. 177: 1009-1020.

Tonegawa, S. 1983. Somatic generation of antibody diversity. Nature 302: 575-581.

Tsubata, T. and M. Reth. 1990. The products of the pre-B cell specific genes $\left(\lambda_{5}\right.$ and $\left.V_{\text {preB }}\right)$ and the immunoglobulin $\mu$ chain form a complex that is transported onto the cell surface. $J$. Exp. Med. 172: 973-976.

Tsubata, T., R. Tsubata, and M. Reth. 1992. Cross-linking of the cell-surface immunoglobulin ( $\mu$-surrogate light chains complex) on pre-B cells induces activation of $V$ gene rearrangements at the immunoglobulin $\kappa$ locus. Int. Immunol. 4: 637-641.

Turka, L.A., D.G. Schatz, M.A. Oettinger, J.J. Chun, C. Gorka, K. Lee, W.T. McCormack, and C.B. Thompson. 1991. Thymocyte expression of the recombination activating genes RAG-1 and RAG-2 can be terminated by $T$ cell receptor cross-linking. Science 253: 778-781.

van Ewijk, W. 1991. T-cell differentiation is influenced by thymic microenvironments. Annu. Rev. Immunol. 9: 591-615.

von Gaudecker, B. 1986. The development of the human thymus microenvironment. Curr. Top. Pathol. 75: 1-41. 


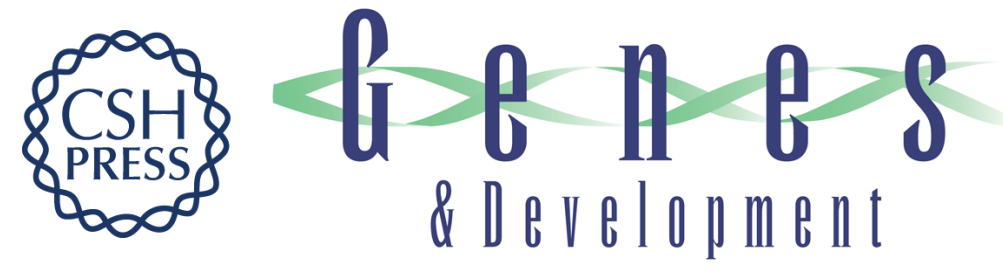

\section{Functional immunoglobulin transgenes guide ordered B-cell differentiation in Rag-1-deficient mice.}

E Spanopoulou, C A Roman, L M Corcoran, et al.

Genes Dev. 1994, 8:

Access the most recent version at doi:10.1101/gad.8.9.1030

References This article cites 77 articles, 34 of which can be accessed free at: http://genesdev.cshlp.org/content/8/9/1030.full.html\#ref-list-1

License

Email Alerting

Receive free email alerts when new articles cite this article - sign up in the box at the top Service right corner of the article or click here.

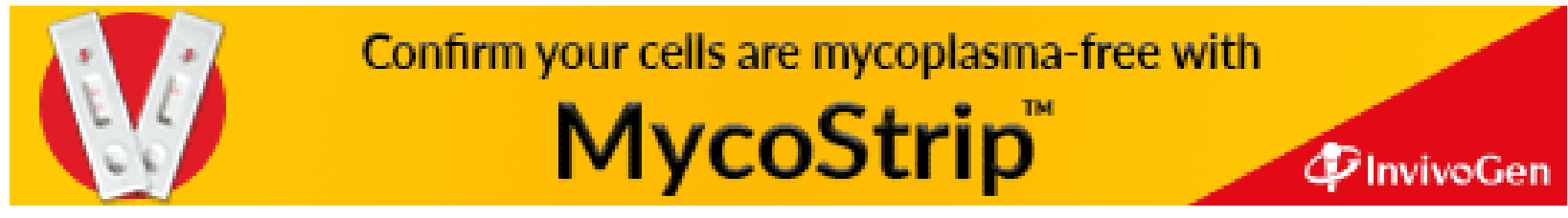

